\title{
COMPARISON BETWEEN BROMINE, CALCIUM, CHLORINE, IODINE, POTASSIUM, MAGNESIUM, MANGANESE, AND SODIUM CONTENTS IN MACRO- AND MICRO-FOLLICULAR COLLOID GOITER
}

VLADIMIR ZAICHICK*

Department of Radionuclide Diagnostics, Medical Radiological Research Centre, Obninsk, Russia. Email: vzaichick@gmail.com Received: 03 August 2021, Revised and Accepted: 23 September 2021

\section{ABSTRACT}

Objective: Colloid nodular goiter (CNG) is the most common disease of the thyroid, even in non-endemic regions, but the etiology of CNG is unclear. It is known that not merely iodine (I) but other chemical elements (ChE) are involved in goitrogenesis. The current study was performed to clarify the preferential accumulation of some ChE either in the colloid or in cells of the thyroid gland.

Methods: Eight ChE: Bromine, calcium, chlorine (Cl), I, potassium, magnesium, manganese, and sodium (Na) in the thyroid tissues with diagnosed CNG were prospectively evaluated in 16 patients with macrofollicular CNG and 13 patients with microfollicular CNG. The control group included thyroid tissue samples from 105 healthy individuals. Measurements were conducted using non-destructive instrumental neutron activation analysis with high-resolution spectrometry of short-lived radionuclides.

Results: It was found that in macrofollicular CNG, the mass fraction of $\mathrm{Cl}$ and Na was 2.57 and 1.82 times, respectively, higher than in tissues of the normal thyroid. In microfollicular CNG, the mass fraction of I was $59 \%$ lower, whereas the mass fraction of Na was $67 \%$ higher than in tissues of the normal thyroid. The level of I in macrofollicular goiter was 2.08 times higher than in microfollicular goiter

Conclusion: There are substantial changes in ChE contents in the goitrous transformed tissue of the thyroid, which depend on the histology of the goiter.

Keywords: Macro- and micro-follicular colloid nodular goiter of thyroid, Intact thyroid, Chemical elements, Instrumental neutron activation analysis.

(C) 2021 The Authors. Published by Innovare Academic Sciences Pvt Ltd. This is an open access article under the CC BY license (http://creativecommons. org/licenses/by/4.0/) DOI: http://dx.doi.org/10.22159/ijms.2021v9i6.42883. Journal homepage: https://innovareacademics.in/journals/index.php/ijms

\section{INTRODUCTION}

Colloid nodular goiter (CNG) is the most common thyroid disease, even in non-endemic regions [1]. CNG is clinically identified in about $4 \%$ of people older than 30 years [1]. CNG is a benign lesion; however, during clinical examination, it can imitate malignant tumors. Furthermore, the origination of CNG can stipulate the beginning of the malignant transformation of the thyroid gland [2]. Up to now, the etiology of CNG is unclear, and it is probably multifactorial [3]. There is an opinion that CNG occurs when the thyroid is not able to meet the metabolic demands of the body with adequate hormone production. The thyroid gland compensates by enlarging, which usually overcomes mild deficiencies of thyroid hormones. For over the $20^{\text {th }}$ century, there was the governing opinion that NG is the straightforward sequel of iodine (I) deficiency. Although, it was found that NG is a frequent disease even in those countries and regions where the inhabitants are never exposed to I shortage [4]. Moreover, it was found that I excess has severe effects on human health and is associated with the presence of thyroidal dysfunctions and autoimmunity, NG and diffuse goiter, benign and malignant tumors of the gland [5-8]. It was also demonstrated that besides the I deficiency and excess, many other dietary, environmental, and occupational factors are associated with the NG incidence [9-11]. Among them, a disruption of evolutionary stable input of many chemical elements (ChE) in the human body after the industrial revolution plays a significant role in the etiology of thyroidal disorders [12].

In addition to I, many other ChE is involved in essential physiological functions [13]. Crucial or toxic (goitrogenic, mutagenic, and carcinogenic) properties of ChE depend on tissue-specific need or tolerance, respectively [13]. Deficiency, overload, or an imbalance of the ChE may result in cellular dysfunction, degeneration, death, and benign or malignant transformation [13-15].
In our earlier studies, the complex of in vivo and in vitro nuclear analytical and related methods was developed and used for the investigation of I and other ChE contents in the normal and pathological thyroid [16-22]. I level in the normal thyroid was scrutinized in relation to age, gender, and some non-thyroidal diseases [23,24]. Hereafter, variations of ChE content with age in the thyroid of males and females were studied, and age and gender dependence of some ChE was perceived [25-41]. In addition, a significant difference between some $\mathrm{ChE}$ contents in normal and cancerous thyroid was demonstrated [42-47]

Histologically, the CNG is cellular hyperplasia of the thyroid acini. There are two histological types of CNG: Macro- and micro-follicular. It is clear that these two types of CNG have different volume ratios, "colloid to cells."

The present study was executed to elucidate the preferential accumulation of some ChE either in the colloid or in cells of the thyroid gland. Having this in mind, we focused on assessing the bromine $(\mathrm{Br})$, calcium $(\mathrm{Ca})$, chlorine $(\mathrm{Cl})$, I, potassium $(\mathrm{K})$, magnesium $(\mathrm{Mg})$, manganese $(\mathrm{Mn})$, and sodium $(\mathrm{Na})$ contents in macro- and microfollicular CNG tissue using non-destructive instrumental neutron activation analysis with high-resolution spectrometry of short-lived radionuclides (INAA-SLR). A further objective was to compare the levels of these ChE in the macro- and micro-follicular CNG separately with those in intact (normal) gland of apparently healthy persons, as well as to find differences between the levels of these ChE in the macro- and micro-follicular CNG.

All studies were approved by the Ethical Committees of the Medical Radiological Research Centre (MRRC), Obninsk. All the procedures performed in studies involving human participants were in accordance with the ethical standards of the institutional and/or national research 
committee and with the 1964 Helsinki Declaration and its later amendments or with comparable ethical standards.

\section{METHODS}

All patients who suffered from $\mathrm{CNG}(\mathrm{n}=29$, mean age $\mathrm{M} \pm \mathrm{SD}$ was $47 \pm 14$ years, range $30-64$ ) were hospitalized in the Head and Neck Department of the MRRC. A thick needle puncture biopsy of suspicious nodules of the thyroid was performed for every patient to permit morphological study of thyroid tissue at these sites and to estimate their $\mathrm{ChE}$ contents. The diagnosis has been confirmed for all patients by clinical and morphological results acquired throughout studies of biopsy and resected materials. The histological conclusion for all thyroidal lesions was the macrofollicular CNG ( $\mathrm{n}=16)$ and microfollicular $\mathrm{CNG}(\mathrm{n}=13)$.

Normal thyroids for the control group samples were drawn out at necropsy from 105 deceased (mean age $44 \pm 21$ years, range 2-87), who had died suddenly. The majority of deaths were due to trauma. A histological examination in the control group was used to control the age norm conformity, also to confirm the absence of micronodules and latent cancer.

All tissue samples were divided into two parts using a titanium scalpel [48]. One was used for morphological study, while the other was for $\mathrm{ChE}$ analysis. After the samples intended for $\mathrm{ChE}$ analysis were weighed, they were freeze-dried and homogenized [49]. The pounded samples weighing about $10 \mathrm{mg}$ (for biopsy) and $100 \mathrm{mg}$ (for resected materials) were used for ChE measurement by INAA-SLR.

Details of sample preparation, activation by neutrons of nuclear reactor, gamma-spectrometry, calibration with biological synthetic standards, and quality insurance using certified reference material (CRM) of International Atomic Energy Agency IAEA H-4 (animal muscle) were presented in our earlier publications concerning the INAA-SLR of ChE contents in human thyroid, scalp hair, and prostate $[18,27,28,50]$.

A dedicated computer program for INAA-SLR mode optimization was used [51]. All the thyroid samples were prepared in duplicate, and mean values of $\mathrm{ChE}$ contents were used in the final calculation. Using Microsoft Office Excel, a summary of the statistics, including arithmetic mean, standard deviation, standard error of the mean, minimum and maximum values, median, and percentiles with 0.025 and 0.975 levels, was calculated for $\mathrm{ChE}$ contents. The distinction in the results between normal thyroid and two groups of CNG (separately macro- and microfollicular), as well as between two groups of CNG, was evaluated by the parametric Student's t-test and non-parametric Wilcoxon-MannWhitney U-test.

\section{IRESULTS}

Table 1 presents certain statistical parameters (arithmetic mean, standard deviation, standard error of the mean, minimal and maximal values, median, and percentiles with 0.025 and 0.975 levels) of the $\mathrm{Br}$, $\mathrm{Ca}, \mathrm{Cl}, \mathrm{I}, \mathrm{K}, \mathrm{Mg}, \mathrm{Mn}$, and $\mathrm{Na}$ mass fraction in normal thyroid $(\mathrm{n}=105)$, macrofollicular CNG $(n=16)$, and microfollicular CNG $(n=13)$.

The comparison of $\mathrm{Br}, \mathrm{Ca}, \mathrm{Cl}, \mathrm{I}, \mathrm{K}, \mathrm{Mg}, \mathrm{Mn}$, and $\mathrm{Na}$ mass fraction in normal thyroid with those in macro- and micro-follicular CNG is shown in Tables 2 and 3, respectively.

The ratios of means and the distinction between mean values of $\mathrm{Br}, \mathrm{Ca}$, $\mathrm{Cl}, \mathrm{I}, \mathrm{K}, \mathrm{Mg}, \mathrm{Mn}$, and Na mass fractions in macro- and micro-follicular CNG are presented in Table 4.

\section{DISCUSSION}

\section{Precision and accuracy of results}

Previously found good agreement of the $\mathrm{Br}, \mathrm{Ca}, \mathrm{Cl}, \mathrm{I}, \mathrm{K}, \mathrm{Mg}$, Mn, and Na contents analyzed by INAA-SLR with the certified data of CRM IAEA $H-4[18,27,28,50]$ indicates an acceptable accuracy of the results obtained in the study of ChE of the thyroid samples presented in Tables 1-4.

The mean values and all chosen statistical parameters were calculated for eight $\mathrm{ChE}(\mathrm{Br}, \mathrm{Ca}, \mathrm{Cl}, \mathrm{I}, \mathrm{K}, \mathrm{Mg}, \mathrm{Mn}$, and $\mathrm{Na}$ ) mass fractions (Table 1 ). The mass fraction of $\mathrm{Br}, \mathrm{Ca}, \mathrm{Cl}, \mathrm{I}, \mathrm{K}, \mathrm{Mg}, \mathrm{Mn}$, and Na was measured in all or a major portion of normal thyroid and CNG samples.

\section{Effect of goitrous transformation on ChE contents}

From Table 2, it is observed that in macrofollicular CNG, the mass fraction of $\mathrm{Cl}$ and $\mathrm{Na}$ is 2.57 and 1.82 times, respectively, higher than

Table 1: Some statistical parameters of $\mathrm{Br}, \mathrm{Ca}, \mathrm{Cl}, \mathrm{I}, \mathrm{K}, \mathrm{Mg}, \mathrm{Mn}$, and $\mathrm{Na}$ mass fraction (mg/kg, dry mass basis) in normal thyroid and colloid nodular goiter of different histology (macro- and micro-follicular)

\begin{tabular}{|c|c|c|c|c|c|c|c|c|c|}
\hline Tissue & Element & Mean & SD & SEM & Min & Max & Median & P 0.025 & P 0.975 \\
\hline Normal & $\mathrm{Br}$ & 16.3 & 11.6 & 1.3 & 1.90 & 66.9 & 13.6 & 2.57 & 51.0 \\
\hline \multirow[t]{6}{*}{$\mathrm{n}=105$} & $\mathrm{Ca}$ & 1692 & 1022 & 109 & 414 & 6230 & 1451 & 460 & 3805 \\
\hline & $\mathrm{Cl}$ & 3400 & 1452 & 174 & 1030 & 6000 & 3470 & 1244 & 5869 \\
\hline & I & 1841 & 1027 & 107 & 114 & 5061 & 1695 & 230 & 4232 \\
\hline & $\mathrm{K}$ & 6071 & 2773 & 306 & 1740 & 14,300 & 5477 & 2541 & 13,285 \\
\hline & $\mathrm{Mg}$ & 285 & 139 & 16.5 & 66.0 & 930 & 271 & 81.6 & 541 \\
\hline & $\mathrm{Mn}$ & 1.35 & 0.58 & 0.07 & 0.510 & 4.18 & 1.32 & 0.537 & 2.23 \\
\hline Macro & $\mathrm{Br}$ & 42.2 & 23.3 & 10.4 & 12.0 & 65.3 & 40.3 & 13.6 & 65.3 \\
\hline \multirow[t]{7}{*}{$n=16$} & $\mathrm{Ca}$ & 1455 & 999 & 258 & 209 & 4333 & 1264 & 278 & 3632 \\
\hline & $\mathrm{Cl}$ & 8749 & 4089 & 1546 & 4226 & 16,786 & 8191 & 4487 & 15,880 \\
\hline & I & 1587 & 1087 & 302 & 300 & 3715 & 1206 & 322 & 3686 \\
\hline & $\mathrm{K}$ & 6254 & 1801 & 465 & 3801 & 9936 & 6185 & 3917 & 9641 \\
\hline & $\mathrm{Mg}$ & 345 & 158 & 41 & 13.0 & 531 & 374 & 30.5 & 531 \\
\hline & $\mathrm{Mn}$ & 1.35 & 0.68 & 0.18 & 0.370 & 2.70 & 1.20 & 0.432 & 2.63 \\
\hline & $\mathrm{Na}$ & 12,211 & 4164 & 1075 & 7229 & 22,381 & 11,056 & 7326 & 20,493 \\
\hline \multirow[t]{7}{*}{$n=13$} & $\mathrm{Ca}$ & 1152 & 610 & 249 & 288 & 2101 & 1092 & 358 & 2025 \\
\hline & $\mathrm{Cl}$ & 9977 & 3939 & 2274 & 5462 & 12,712 & 11,756 & 5777 & 12,664 \\
\hline & I & 762 & 600 & 173 & 141 & 1936 & 586 & 173 & 1929 \\
\hline & $\mathrm{K}$ & 6932 & 2783 & 1052 & 3353 & 10,318 & 6461 & 3423 & 10,193 \\
\hline & $\mathrm{Mg}$ & 328 & 134 & 51 & 122 & 497 & 371 & 134 & 486 \\
\hline & $\mathrm{Mn}$ & 2.40 & 1.70 & 0.69 & 0.450 & 5.50 & 1.93 & 0.619 & 5.16 \\
\hline & $\mathrm{Na}$ & 11,167 & 2472 & 1009 & 8065 & 14,584 & 11,518 & 8153 & 14,329 \\
\hline
\end{tabular}

M: Arithmetic mean, SD: Standard deviation, SEM: Standard error of the mean, Min: Minimum value, Max: Maximum value, $P$ 0.025: Percentile with 0.025 level, $P$ 0.975: Percentile with 0.975 level 
Table 2: Differences between mean values $(\mathrm{M} \pm \mathrm{SEM})$ of $\mathrm{Br}, \mathrm{Ca}, \mathrm{Cl}, \mathrm{I}, \mathrm{K}, \mathrm{Mg}$, Mn, and Na mass fraction (mg/kg, dry mass basis) in normal thyroid and macrofollicular colloid nodular goiter

\begin{tabular}{|c|c|c|c|c|c|}
\hline \multirow[t]{2}{*}{ Element } & \multicolumn{3}{|c|}{ Thyroid tissue } & \multirow[t]{2}{*}{ U-test p } & \multirow{2}{*}{$\begin{array}{c}\text { Ratio } \\
\text { Goiter to norm }\end{array}$} \\
\hline & Normal thyroid $n=105$ & Macrofollicular goiter $n=16$ & Student's t-test $\mathrm{p} \leq$ & & \\
\hline $\mathrm{Br}$ & $16.3 \pm 1.3$ & $42.2 \pm 10.4$ & 0.067 & $>0.05$ & 2.59 \\
\hline $\mathrm{Ca}$ & $1692 \pm 109$ & $1455 \pm 258$ & 0.371 & $>0.05$ & 0.86 \\
\hline $\mathrm{Cl}$ & $3400 \pm 174$ & $8749 \pm 1546$ & 0.013 & $\leq 0.01$ & 2.57 \\
\hline I & $1841 \pm 107$ & $1587 \pm 302$ & 0.439 & $>0.05$ & 0.86 \\
\hline $\mathrm{K}$ & $6071 \pm 306$ & $6254 \pm 465$ & 0.745 & $>0.05$ & 1.03 \\
\hline $\mathrm{Mn}$ & $1.35 \pm 0.07$ & $1.35 \pm 0.18$ & 0.966 & $>0.05$ & 1.00 \\
\hline $\mathrm{Na}$ & $6702 \pm 1785$ & $12,211 \pm 1075$ & 0.00015 & $\leq 0.01$ & 1.82 \\
\hline
\end{tabular}

M: Arithmetic mean, SEM: Standard error of the mean, significant values are in bold

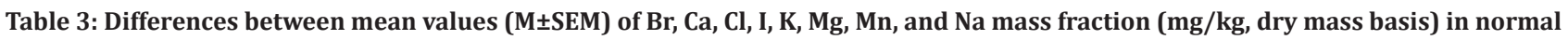
thyroid and microfollicular colloid nodular goiter

\begin{tabular}{|c|c|c|c|c|c|}
\hline \multirow[t]{2}{*}{ Element } & \multicolumn{3}{|c|}{ Thyroid tissue } & \multirow[t]{2}{*}{ U-test p } & \multirow{2}{*}{$\begin{array}{c}\text { Ratio } \\
\text { Goiter to norm }\end{array}$} \\
\hline & Normal thyroid $n=105$ & Microfollicular goiter $n=13$ & Student's t-test $\mathrm{p} \leq$ & & \\
\hline $\mathrm{Br}$ & $16.3 \pm 1.3$ & $19.4 \pm 3.5$ & 0.464 & $>0.05$ & 1.19 \\
\hline $\mathrm{Ca}$ & $1692 \pm 109$ & $1152 \pm 249$ & 0.078 & $>0.05$ & 0.68 \\
\hline $\mathrm{Cl}$ & $3400 \pm 174$ & $9977 \pm 2274$ & 0.101 & $\leq 0.05$ & 2.93 \\
\hline I & $1841 \pm 107$ & $762 \pm 173$ & 0.00003 & $\leq 0.01$ & 0.41 \\
\hline $\mathrm{K}$ & $6071 \pm 306$ & $6932 \pm 1052$ & 0.458 & $>0.05$ & 1.14 \\
\hline $\mathrm{Mg}$ & $285 \pm 17$ & $328 \pm 51$ & 0.436 & $>0.05$ & 1.15 \\
\hline $\mathrm{Mn}$ & $1.35 \pm 0.07$ & $2.40 \pm 0.69$ & 0.192 & $>0.05$ & 1.78 \\
\hline $\mathrm{Na}$ & $6702 \pm 1785$ & $11,167 \pm 1009$ & 0.0063 & $\leq 0.01$ & 1.67 \\
\hline
\end{tabular}

M: Arithmetic mean, SEM: Standard error of the mean, significant values are in bold

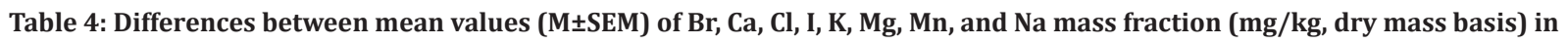
macro- and micro-follicular colloid nodular goiter

\begin{tabular}{|c|c|c|c|c|c|}
\hline \multirow[t]{2}{*}{ Element } & \multicolumn{3}{|c|}{ Thyroid tissue } & \multirow[t]{2}{*}{ U-test p } & \multirow{2}{*}{$\frac{\text { Ratio }}{\text { Macro to Micro }}$} \\
\hline & Macrofollicular goiter $n=16$ & Microfollicular goiter $n=13$ & Student's t-test $\mathrm{p} \leq$ & & \\
\hline $\mathrm{Br}$ & $42.2 \pm 10.4$ & $19.4 \pm 3.5$ & 0.094 & $>0.05$ & 2.18 \\
\hline $\mathrm{Cl}$ & $8749 \pm 1546$ & $9977 \pm 2274$ & 0.678 & $>0.05$ & 0.88 \\
\hline I & $1587 \pm 302$ & $762 \pm 173$ & 0.028 & $\leq 0.01$ & 2.08 \\
\hline $\mathrm{K}$ & $6254 \pm 465$ & $6932 \pm 1052$ & 0.571 & $>0.05$ & 0.90 \\
\hline $\mathrm{Mg}$ & $345 \pm 41$ & $328 \pm 51$ & 0.801 & $>0.05$ & 1.05 \\
\hline $\mathrm{Mn}$ & $1.35 \pm 0.18$ & $2.40 \pm 0.69$ & 0.194 & $>0.05$ & 0.56 \\
\hline $\mathrm{Na}$ & $12,211 \pm 1075$ & $11,167 \pm 1009$ & 0.489 & $>0.05$ & 1.09 \\
\hline
\end{tabular}

M: Arithmetic mean, SEM: Standard error of mean, significant values are in bold

in tissues of the normal thyroid. From Table 3, it is observed that in microfollicular CNG, the mass fraction of I is $59 \%$ lower, whereas the mass fraction of $\mathrm{Na}$ is $67 \%$ higher than in tissues of the normal thyroid. Thus, if we accept the ChE contents in thyroid glands in the control group as a norm, we have to conclude that the $\mathrm{Cl}$, I, and $\mathrm{Na}$ level in thyroid tissue can be notably changed with a goitrous transformation.

Association between ChE levels and relative volume of colloid and cells

Comparison mass fraction of $\mathrm{Br}, \mathrm{Ca}, \mathrm{Cl}, \mathrm{I}, \mathrm{K}, \mathrm{Mg}, \mathrm{Mn}$, and $\mathrm{Na}$ in macro- and micro-follicular CNG shown that level of I in macrofollicular goiter is 2.08 times higher than in microfollicular goiter (Table 4). Because the relative volume of colloid in the macrofollicular CNG is higher than in the microfollicular $\mathrm{CNG}$, it is possible to conclude that I increasingly associated with colloid.

\section{Comparison with published data}

The published data on ChE contents in the CNG compared to normal levels are very sparse and contradictory. For example, information about $\mathrm{Cl}$ content in $\mathrm{CNG}$ was not found. Merely, one paper with results on Na level in normal thyroid and CNG was published in 1963 by Kamenev [52], but changes of this electrolyte level in goitrous thyroid were not shown. A relative good agreement there is only for I, since most of the published studies showed a significant decrease of I content in the CNG [53-56].

Information on the ChE contents in macro- or micro-follicular CNG, also about the association between $\mathrm{ChE}$ level and relative volume of colloid and cells in goitrous tissue, was not found.

\section{Limitations}

This study has some limitations. First, analytical techniques used in this study measure merely eight $\mathrm{ChE}(\mathrm{Br}, \mathrm{Ca}, \mathrm{Cl}, \mathrm{I}, \mathrm{K}, \mathrm{Mg}, \mathrm{Mn}$, and $\mathrm{Na}$ ) mass fractions. Future studies should be aimed toward using other analytical methods which will elongate the list of $\mathrm{ChE}$ investigated in normal and goitrous thyroid. Second, the sample size of macro- or microfollicular CNG groups was relatively small and averted investigations of $\mathrm{ChE}$ contents in CNG group using differentials such as gender, stage of disease, and dietary habits of healthy persons and patients with CNG. Finally, the generalization of our outcomes may be bounded 
to the Russian population. Despite these constraints, this study provides evidence on goiter-specific tissue $\mathrm{Cl}$, I, and $\mathrm{Na}$ level alteration demonstrates associations between I and relative volume of colloid in $\mathrm{CNG}$, and shows the necessity to continue ChE research of CNG of different histology.

\section{CONCLUSION}

In this work, ChE analysis was carried out in the tissue samples of normal and goitrous thyroid using INAA-SLR. It was shown that INAA-SLR is an adequate analytical tool for the non-destructive determination of $\mathrm{Br}, \mathrm{Ca}$ $\mathrm{Cl}, \mathrm{I}, \mathrm{K}, \mathrm{Mg}, \mathrm{Mn}$, and $\mathrm{Na}$ content in the tissue samples of human thyroid in norm and pathology, including needle biopsy cores. It was perceived the considerable changes in $\mathrm{ChE}$ contents in the goitrous transformed tissue of thyroid, which depends on the histology of goiter. It was found that I predominately accumulates in colloid of CNG.

\section{ACKNOWLEDGMENTS}

The authors are exceedingly grateful to Profs. B.M. Vtyurin and V.S. Medvedev, Medical Radiological Research Center, Obninsk, as well as to Dr. Yu. Choporov, Head of the Forensic Medicine Department of City Hospital, Obninsk, for supplying thyroid samples.

\section{REFERENCES}

1. Stuchi LP, Castanhole-Nunes MM, Maniezzo-Stuchi N, BiselliChicote P, Henrique T, Neto JA, et al. EGFA and NFE2L2 gene expression and regulation by microRNAs in thyroid papillary cancer and colloid goiter. Genes (Basel) 2020;11:954.

2. Campbell MJ, Seib CD, Candell L, Gosnell JE, Duh QY, Clark OH, et al. The underestimated risk of cancer in patients with multinodular goiters after a benign fine needle aspiration. World J Surg 2015;39:695-700.

3. Frilling A, Liu C, Weber F. Benign multinodular goiter. Scand J Surg 2004;93:278-81.

4. Derwahl M, Studer H. Multinodular goitre: Much more to it than simply iodine deficiency. Baillieres Best Pract Res Clin Endocrinol Metab 2000;14:577-600.

5. Zaichick V. Iodine excess and thyroid cancer. J Trace Elem Exp Med 1998;11:508-9.

6. Zaichick V, Iljina T. Dietary iodine supplementation effect on the rat thyroid 131I blastomogenic action. In: Die Bedentung der Mengenund Spurenelemente. 18. Arbeitstangung. Jena: Friedrich-SchillerUniversität; 1998. p. 294-306.

7. Kim S, Kwon YS, Kim JY, Hong KH, Park YK. Association between iodine nutrition status and thyroid disease-related hormone in Korean adults: Korean national health and nutrition examination survey VI (2013-2015). Nutrients 2019;11:2757.

8. Vargas-Uricoechea P, Pinzón-Fernández MV, Bastidas-Sánchez BE, Jojoa-Tobar E, Ramírez-Bejarano LE, Murillo-Palacios J. Iodine status in the colombian population and the impact of universal salt iodization: A double-edged sword? J Nutr Metab 2019;2019:6239243.

9. Stojsavljević A, Rovčanin B, Krstić D, Borković-Mitić S, Paunović I, Diklić A, et al. Risk assessment of toxic and essential trace metals on the thyroid health at the tissue level: The significance of lead and selenium for colloid goiter disease. Expo Health 2019;12:255-64.

10. Fahim YA, Sharaf NE, Hasani IW, Ragab EA, Abdelhakim HK Assessment of thyroid function and oxidative stress state in foundry workers exposed to lead. J Health Pollut 2020;10:200903.

11. Liu M, Song J, Jiang Y, Lin Y, Peng J, Liang H, et al. A case-control study on the association of mineral elements exposure and thyroid tumor and goiter. Ecotoxicol Environ Saf 2021;208:111615.

12. Zaichick V. Medical elementology as a new scientific discipline. J Radioanal Nucl Chem 2006;269:303-9.

13. Moncayo R, Moncayo H. A post-publication analysis of the idealized upper reference value of $2.5 \mathrm{mIU} / \mathrm{L}$ for TSH: Time to support the thyroid axis with magnesium and iron especially in the setting of reproduction medicine. BBA Clin 2017;7:115-9.

14. Beyersmann D, Hartwig A. Carcinogenic metal compounds: Recent insight into molecular and cellular mechanisms. Arch Toxicol 2008;82:493-512.

15. Martinez-Zamudio R, Ha HC. Environmental epigenetics in metal exposure. Epigenetics 2011;6:820-7.

16. Zaĭchik VE, RaibukhinYuS, Melnik AD, Cherkashin VI. Neutronactivation analysis in the study of the behavior of iodine in the organism.
Med Radiol (Mosk) 1970;15:33-6

17. Zaĭchik VE, Matveenko EG, Vtiurin BM, Medvedev VS. Intrathyroid iodine in the diagnosis of thyroid cancer. Vopr Onkol 1982;28:18-24.

18. Zaichick V, Tsyb AF, Vtyurin BM. Trace elements and thyroid cancer. Analyst 1995; 120:817-21.

19. Zaichick V, Choporov Y. Determination of the natural level of human intra-thyroid iodine by instrumental neutron activation analysis. J Radioanal Nucl Chem 1996;207:153-61.

20. Zaichick V. In vivo and in vitro application of energy-dispersive XRF in clinical investigations: Experience and the future. J Trace Elem Exp Med 1998;11:509-10.

21. Zaichick V, Zaichick S. Energy-dispersive X-ray fluorescence of iodine in thyroid puncture biopsy specimens. J Trace Microprobe Tech 1999; 17:219-32.

22. Zaichick V. Relevance of, and potentiality for in vivo intrathyroidal iodine determination. Ann N Y Acad Sci 2000;904:630-2.

23. Zaichick V, Zaichick S. Normal human intrathyroidal iodine. Sci Total Environ 1997;206:39-56.

24. Zaichick V, Human intrathyroidal iodine in health and non-thyroidal disease. In: Abdulla M, Bost M, Gamon S, Arnaud P, Chazot G. editors. New Aspects of Trace Element Research. London, Tokyo: SmithGordon and Nishimura; 1999. p. 114-9.

25. Zaichick V, Zaichick S. Age-related changes of some trace element contents in intact thyroid of females investigated by energy dispersive X-ray fluorescent analysis. Trends Geriatr Healthc 2017;1:31-8.

26. Zaichick V, Zaichick S. Age-related changes of some trace element contents in intact thyroid of males investigated by energy dispersive X-ray fluorescent analysis. MOJ Gerontol Geriatr 2017;1:00028.

27. Zaichick V, Zaichick S. Age-related changes of $\mathrm{Br}, \mathrm{Ca}, \mathrm{Cl}, \mathrm{I}, \mathrm{K}, \mathrm{Mg}$, $\mathrm{Mn}$, and $\mathrm{Na}$ contents in intact thyroid of females investigated by neutron activation analysis. Curr Updat Aging 2017;1:5.1.

28. Zaichick V, Zaichick S. Age-related changes of Br, Ca, Cl, I, K, Mg, $\mathrm{Mn}$, and $\mathrm{Na}$ contents in intact thyroid of males investigated by neutron activation analysis. J Aging Age Relat Dis 2017;1:1002.

29. Zaichick V, Zaichick S. Age-related changes of Ag, Co, Cr, Fe, Hg, Rb, $\mathrm{Sb}, \mathrm{Sc}, \mathrm{Se}$, and $\mathrm{Zn}$ contents in intact thyroid of females investigated by neutron activation analysis. J Gerontol Geriatr Med 2017;3:015.

30. Zaichick V, Zaichick S. Age-related changes of Ag, Co, Cr, Fe, Hg, $\mathrm{Rb}, \mathrm{Sb}, \mathrm{Sc}, \mathrm{Se}$, and $\mathrm{Zn}$ contents in intact thyroid of males investigated by neutron activation analysis. Curr Trends Biomed Eng Biosci 2017;4:555644.

31. Zaichick V, Zaichick S. Effect of age on chemical element contents in female thyroid investigated by some nuclear analytical methods. Micromedicine 2018;6:47-61.

32. Zaichick V, Zaichick S. Neutronactivationand X-ray fluorescent analysis in study of association between age and chemical element contents in thyroid of males. Open Access J Biomed Eng Biosci 2018;2:202-12.

33. Zaichick V, Zaichick S. Variation with age of chemical element contents in females' thyroids investigated by neutron activation analysis and inductively coupled plasma atomic emission spectrometry. J Biochem Anal Stud 2018;3:1-10.

34. Zaichick V, Zaichick S. Association between age and twenty chemical element contents in intact thyroid of males. SM Gerontol Geriatr Res 2018;2:1014.

35. Zaichick V, Zaichick S. Associations between age and 50 trace element contents and relationships in intact thyroid of males. Aging Clin Exp Res 2018;30:1059-70.

36. Zaichick V, Zaichick S. Possible role of inadequate quantities of intra-thyroidal bromine, rubidium and zinc in the etiology of female subclinical hypothyroidism. EC Gynaecol 2018;7:107-15.

37. Zaichick V, Zaichick S. Possible role of inadequate quantities of intrathyroidal bromine, calcium and magnesium in the etiology of female subclinical hypothyroidism. Int Gynecol Womens Health 2018;1:52-9.

38. Zaichick V, Zaichick S. Possible role of inadequate quantities of intrathyroidal cobalt, rubidium and zinc in the etiology of female subclinical hypothyroidism. Womens Health Sci J 2018;2:000108.

39. Zaichick V, Zaichick S. Association between female subclinical hypothyroidism and inadequate quantities of some intra-thyroidal chemical elements investigated by X-ray fluorescence and neutron activation analysis. Gynaecol Perinatol 2018;2:340-55.

40. Zaichick V, Zaichick S. Investigation of association between the high risk of female subclinical hypothyroidism and inadequate quantities of twenty intra-thyroidal chemical elements. Clin Res Gynecol Obstet 2018;1:1-18.

41. Zaichick V, Zaichick S. Investigation of association between the high risk of female subclinical hypothyroidism and inadequate quantities of intra-thyroidal trace elements using neutron activation and inductively 
coupled plasma mass spectrometry. Acta Sci Med Sci 2018;2:23-37.

42. Zaichick V. Zaichick S. Trace element contents in thyroid cancer investigated by energy dispersive X-ray fluorescent analysis. Am J Cancer Res Rev 2018;2:5.

43. Zaichick V, Zaichick S. Trace element contents in thyroid cancer investigated by instrumental neutron activation analysis. J Oncol Res 2018;2:1-13.

44. Zaichick V, Zaichick S. Variation in selected chemical element contents associated with malignant tumors of human thyroid gland. Cancer Stud 2018;2:2

45. Zaichick V, Zaichick S. Twenty chemical element contents in normal and cancerous thyroid. Int J Hematol Blood Dis 2018;3(2):1-13.

46. Zaichick V, Zaichick S. Levels of chemical element contents in thyroid as potential biomarkers for cancer diagnosis (a preliminary study). J Cancer Metastasis Treat 2018;4:60.

47. Zaichick V, Zaichick S. Fifty trace element contents in normal and cancerous thyroid. Acta Sci Cancer Biol 2018;2:21-38

48. Zaichick V, Zaichick S. Instrumental effect on the contamination of biomedical samples in the course of sampling. J Anal Chem 1996;51:1200-5.

49. Zaichick V, Zaichick S. A search for losses of chemical elements during freeze-drying of biological materials. J Radioanal Nucl Chem $1997 ; 218: 249-53$
50. Zaichick V. Applications of synthetic reference materials in the medical radiological research centre. Fresenius J Anal Chem 1995;352:219-23.

51. Korelo AM, Zaichick V. Software to optimize the multielement INAA of medical and environmental samples. In: Activation Analysis in Environment Protection. Dubna, Russia: Joint Institute for Nuclear Research;1993. p. 326-32.

52. Kamenev VF. About trace element contents in thyroid of adults. In: Trace Elements in Agriculture and Medicine. Ulan-Ude: Buryatia Publishing-House; 1963. p. 12-6.

53. Le Blank AD, Bell RL, Johnson PhC. Measurement of 127J concentration in thyroid tissue by X-ray fluorescence. J Nucl Med 1973;14:816-9.

54. Kohler H, Studer H. Biochemical changes in "warm" and "cold" thyroid nodules. Therapiewoche 1981;31:1539-45.

55. Tadros TG, Maisey MN, Ng Tang Fui SC, Turner P. The iodine concentration in benign and malignant thyroid nodules measured by X-ray fluorescence. Br J Radiol 1981;54:626-9.

56. Błazewicz A, Dolliver W, Sivsammye S, Deol A, Randhawa R, OrliczSzczesna G, et al. Determination of cadmium, cobalt, copper, iron, manganese, and zinc in thyroid glands of patients with diagnosed nodular goitre using ion chromatography. J Chromatogr B Analyt Technol Biomed Life Sci 2010;878:34-8. 